\title{
Financial Decision Making among the Dual-Income Families in Malaysia
}

\author{
Zaimah, R. ${ }^{1}$ \\ Jariah Masud2 \\ Sharifah Azizah Haron ${ }^{3}$ \\ Sarmila, M.S. ${ }^{4}$ \\ Abd Hair Awang 5 \\ ${ }^{1}$ Senior Lecturer, Faculty of Social Sciences and Humanities, Universiti Kebangsaan Malaysia \\ zaimahr@ukm.edu.my \\ 2 Professor, Institute of Gerontology, Universiti Putra Malaysia \\ jariahmasud@yahoo.com \\ ${ }^{3}$ Associate Professor, Faculty Human Ecology, Universiti Putra Malaysia \\ sh.azizah@upm.putra.edu.my \\ ${ }_{4}$ Senior Lecturer, Faculty of Social Sciences and Humanities, Universiti Kebangsaan Malaysia \\ sarmila.mdsum@ukm.edu.my \\ ${ }^{5}$ Associate Professor, Faculty of Social Sciences and Humanities, Universiti Kebangsaan Malaysia \\ hair@ukm.edu.my
}

\section{Doi:10.5901/mjss.2015.v6n4s3p70}

\section{Abstract}

This paper is part of the Financial Well-Being Research among the Public Sector Workers in Malaysia, carried out in 2008. The paper seeks to identify the husbands' and wives' financial decision making in a dual-income families. The unit of analysis is the individual, either the husband or the wife. A total of 415 respondents was included in this analysis. Financial decision making is measured using a five scale, i.e. 1=husband; 2=wife; 3=child; 4=together; and 5=individuals. Three major financial decision making patterns obtained in the findings are similar to the findings obtained in the previous studies, namely decision-making by the husband, decision making by the wife, and financial decision making were made by both the husband and the wife. The financial decision making by the husband involved big expenditure with high commitment. Decision making by the wife was more focused on the needs of the family related expenses. While decision making by the husband and wife tends to relate to the children's needs. In addition, the findings also showed that the larger income contribution of the family provides greater opportunities in the decision making. However, decision-making in a dual-income family is also influenced by the religion and culture.

Keywords: Husband's decision making, wife's decision making, spouses' decision making, dual-income family, resources theory.

\section{Introduction}

The participation of women in the employment creates a dual-income family structure (Foster, 1988; Foster \& Mammen, 1992; Goldsmith, 2005; Blau, Ferber \& Winkler, 2006). Dual-income family means a family consisting of husband and wife who are employed and have income (Winkler, 1998; Goldsmith, 2005; Blau, Ferber \& Winkler, 2006), and this pattern is growing in Malaysia (Sabitha 2005; Economic Planning Unit, 2006; Ahmad, 2008; Zaimah, 2013). The dualincome family phenomenon is proven to be able to increase the family income and it has become a necessity (Ahmad, 1999; Jamilah, 2001; Noraini, 2001; Sabitha, 2011; Zaimah, 2011; Zaimah et al., 2012), especially in the light of the increase of cost of living these days.

In fact, the increase of income in the dual-income families provide guarantee of the financial strength to the family (Goldsmith, 2005; Gupta, Walker \& Huston, 2008), particularly among couples in a dual-income family itself (Winkler, 1998; Blau, Ferber \& Winkler, 2006). This is true for every dual-income families to have their own financial resources (Goldsmith, 2005; Yilmazer \& Lyons, 2010). Therefore, they do not rely solely on the spouse's financial resources, especially if there are unwanted incidents such as death, accident or loss of spouse's employment. Thus, dual-income family should have a better level of financial well-being. 
Apart from the likely of achieving a better financial well-being, the dual-income family structure are expected to cause changes in the financial decision making patterns within the family as both the husband and wife contribute income to the family (Edgel, 1980; Grossbard-Shectman, 2001; Bernasek \& Bajtelsmit, 2002; Samsinar, Wong, Ruhana et al., 2004). Thus, this research aims to identify the dual-income family's financial decision making patterns in Malaysia. More specifically, the study will discuss the financial decision making patterns by the husband, financial decision making by the wife, and also financial decision making by both the husband and the wife.

\section{Literature Review}

Financial decision making is defined as the individual's authority to a financial decision making and is usually described in terms of the pattern of financial decision making, whether it is done jointly between the husband and wife, or one of the more dominating (Bernasek \& Bajtelsmit, 2002).

\subsection{Financial decision making}

Financial decision making involves the relationship between money and power in the family, especially in the dual-income families. The relationship has a certain direction, i.e. those who have incomes will have a major influence in the family decision-making (Hertz, 1992). If the assumption is true, the phenomenon of the increasing participation of women (wives) in employment and contributing to the family income will produce a different pattern of decision-making for couples who are both working.

According to Safilios-Rothschild (1969 in Edgel 1980) who has studied the decision making among professional workers and their wives finds that, very important decision tend to be dominated by the husband. Between the important and not important decisions, the decision was jointly made. Financial related decision making that is categorized as the most important perception is made by the husband. In other words, husband has more opportunities in making decisions involving important things (that involve large amount of money), while the wife only had the opportunity to make decisions in small matters.

Normally, the family financial management has two main features, namely the one who has the power to make decisions and who manage their finances. Decision-making authority is usually described in terms of the pattern of financial decision making, whether it is done jointly between the husband and wife, or by dominating ones. In many instances, women were found to be playing a bigger role as a financial manager in the family (Coleman \& Ganong, 1989; Muske, 1995; Muske \& Winter, 2001).

Financial decision making is associated with the distribution of financial resources within a family, and it depends on who has the source of income in the family (Grassbard-Shectmen, 2003). In fact, the authority or the right of an individual in making financial decision also has an impact on the relationship and financial well-being, especially in terms of financial satisfaction (Bernasek \& Bajtelsmit, 2002). That means, the opportunity to make decisions in matters related to finance also gave financial satisfaction.

In the context of financial decision-making, women who work outside the home, have income and own property has the advantage of expression in the family financial decision making compared to those who do not have their own sources of income (Grassbard-Shectmen, 2003). The possibility for a wife to have more power in the financial decision making process has a significant effect of about 20 to 25 percent amongst dual-income couples if the wife has a higher income than their husbands (Winkler, 1998).

The findings by Bernasek and Baitelsmit (2002) concluded that, women participation in the family financial decision making are significant and have a positive relationship with the contribution of their income to the family. Women will have more power to make financial decision if she contributes a significant share to the family income. But women are less instrumental in making decisions related to the family savings and investments. Instead, men are more likely to make financial decision in the family when their level of education, level of income and financial assets are higher than the women (Lindamood \& Hanna, 2006).

Samsinar et al. (2004) described that the gender factor also plays an important role in the family decision making. Their study found that women also have an important role in purchasing decision making in the family. Normally, the husband and wife will decide collectively in making decisions pertaining to the purchasing of goods or spending money to the family. Therefore, it is difficult to determine the specific factors that influence the decision-making patterns (Samsinar et al., 2004). In addition, women were prefer to avoid risks in the financial decisions making than men even if they acquire greater financial resources than men (Stendardi \& Graham, 2000; Yilmazer \& Lyons, 2010). For example, Yilmazer and Lyons (2010) found that married women who have greater power to the family's financial resources are less 
keen to invest in risky assets.

Study by Mano-Negrin and Katz (2003) on the employed spouses economic behavior found that there were three patterns of spouse's income distribution, that are, the traditional couples, modern couples and individualistic couples. The traditional couples do not share their income, but have accounts that are jointly managed. Modern couples share the income, but have separate accounts. Whereas individualistic couples do not share their income and have separate accounts. However, modern couples claim that they often make their own decisions when they make a purchase or invest their earnings.

In summary, the previous studies found that spouses often make joint decisions in matters pertaining to housing, education, recreation, medical and family expenses (Deacon \& Firebough, 1988). Men have the higher level of financial well-being than women because they have the opportunity to enjoy higher income and receive more pension (Davis, 1993). In fact, significant differences exist between men and women in the purchasing behavior and financial satisfaction. The fact is, men have greater authority in the financial decision making that also affect the financial well-being.

\subsection{Theoretical framework}

The theory of resources was introduced by Robert Blood and Donald Wolfe in 1960. Most of the studies on power in marriage were using this theory as a framework for research (Rodman, 1972; Straus \& Yodanis, 1995; Peyton, Pitts \& Kamery, 2004). The resources theory asserts that the 'balance of power' in decision-making would be in favor of the spouse who contributed the most resources in the marriage relationship. The family members who have vast resources to meet the needs and goals of other family members were designated as having greater power.

In fact, the power of women in decision-making is assumed to increase with the increasing resources contributed to the family. It means, resources contributed by the spouse in the family has a significant impact on the financial decision making. According to Blood and Wolfe (1960), decision-making was found to be directly proportioned to the income, education and occupational status.

On the other hand, Rodman (1972) failed to prove the main assumptions of the theory. His research shows that the husband's occupation, education and income status were negatively related to the power that belongs to the family. Therefore, he treated that the relations between resources with the marriage power is dependent on the role of the gender which is also influenced by the socio-cultural factors in the local community (Ahmad, 1999; Norzareen \& Nobaya, 2010; Kaur, 2008).

In addition, Bonke (2008) found that the contribution of the income between the husband and the wife in the family also affects the financial satisfaction. Their study found that the husband's financial satisfaction decreases and the wife's financial satisfaction increases when the wives earned more than their husbands.

\section{Research Methodology}

This paper seeks to identify the pattern of the dual-income families financial decision making among the public sector workers who are married. The data used in this study were from a study of the Financial Well-being among public sector in Malaysian, 2008. Discussions involving the results of analysis on 415 respondents among the employees of the dualincome families. The questionnaire was used as an instrument in this study. Respondents are required to answer a 'who most often' make decisions about spending money on the 14 related financial decisions in the family, namely food, meals and beverages outside the home, clothing and footwear, communication equipment, household electrical appliances, furniture/home furnishings, vehicles, real estates, medical, education, life insurance, education insurance, family vacations, and contribution to the parents. Financial decision making is measured using a five scale, i.e. 1=husband; 2=wife; 3=child; 4=together; and 5=individuals. Factor analysis was used to classify the 14 items used to measure the financial decision making. Financial decisions making score were derived from the total score of husband's financial decisions and the total score of wives' financial decisions of 10 statements (only 10 items accepted after factor analysis was conducted). While descriptive analysis (frequency, percentage, mean and standard deviation) was used to analyse the data for overall discussion. The ANOVA test was used to compare the financial decision making based on the husband's and wife's income contribution to the family. 


\section{Findings and Discussion}

\subsection{Socio-economic backgrounds of respondent}

The socio-economic background of the respondent is shown in Table 1. Among the 415 respondents, 47 percent were male and 53 percent were female. The average age of the respondents was 38 years old. In particular, approximately 50 percent were in the age range of less than 40 years old. Although the average years of marriage among the respondents were 11 years, more than half (55.4 percent) of the respondents were married less than 10 years. The average number of children was 2 persons. Meanwhile, the average of working years was 13 years and the data showed the highest percent (51.6\%) within less than 10 years. It was consistent with the data that showed more respondents were among the younger age.

The majority of respondents were non-universities graduates (59.8\%) and only 40.2 percent were graduates. More male respondents (51.8\%) were graduates compared to female (30.0\%) respondents. The average monthly income of the respondents was RM3,579.00. It involved 40 percent from middle income family in Malaysia, range from RM2,300.00 to RM5,599.00 (Economic Planning Unit, 2010). The average monthly expenses of the respondents was RM2,372.00. The finding showed that the husband still held the responsibility as the breadwinner in dual-income families.

Among the total number of respondents, nearly 55 percent of the respondents owned their own house. The average monthly house loan payment is RM726.50 with the range from RM140.00 and RM3,000.00. The husband contributed more to the family income (64.1\%) compared to the wife. The equal sharing of income between husband and wife showed a low percentage (11.0\%). The portion from the wife only amounted up to 24.8 percent. If a comparison is made between male respondents and female respondents, the three categories of income contribution shows the same pattern, the husband contributed more income than his wife even though both of them were working.

Table (1). Socio-economic background of respondent

\begin{tabular}{lcc}
\hline Socio-economic background & Frequency (\%) & Mean (S.D.) \\
\hline Gender: & $195(47.0)$ & - \\
Male & $220(53.0)$ & - \\
Female & - & $38(9.45)$ \\
Age & - & $11(9.18)$ \\
Duration of marriage & - & $2(1.77)$ \\
Number of children & - & $13(10.20)$ \\
Duration of work & & \\
Level of education: & $166(40.2)$ & - \\
University graduates & $249(59.8)$ & - \\
Non graduate & - & $3579(2421.39)$ \\
Monthly income (RM) & - & $2372(1575.37)$ \\
Monthly expense (RM) & - & $228(54.9)$ \\
Home ownership & & - \\
Contribution to family income: & $266(64.1)$ & - \\
Husband $>$ wife & $46(11.1)$ & - \\
Husband $=$ wife & $103(24.8)$ & - \\
Husband < wife & & \\
\hline
\end{tabular}

\subsection{Distribution of the dual-income family's financial decision making}

Table 2 shows the pattern of the financial decision making in the family. Financial decision making by the husband who had the highest percentage can be seen in eleven cases, namely meals outside the home $(56.6 \%)$, communication equipment (61.9\%), household electrical appliances (52.0\%), vehicles (78.3\%), real estates (66.3\%), medicine (47.1\%), children's education (39.3\%), life insurance (54.2\%), education insurance (43.9\%), family vacations $(44.1 \%)$ and money for the parents (39.3\%). Six of them recorded percentage share that exceeds 50 percent. In general, these findings clearly show that men have more power in the financial decision making, especially those involving large expenditures and high commitments. 
Table (2). Distribution of the dual-income financial decision making

\begin{tabular}{|c|c|c|c|c|c|c|}
\hline \multirow{2}{*}{\multicolumn{2}{|c|}{ Financial decision making (FDM) }} & \multicolumn{5}{|c|}{ Frequency (\%) } \\
\hline & & \multirow{2}{*}{$\begin{array}{l}\text { Husband } \\
111(26.7)\end{array}$} & \multirow{2}{*}{$\begin{array}{c}\text { Wife } \\
259(62.4)\end{array}$} & \multirow{2}{*}{$\begin{array}{c}\text { Children } \\
2(0.5)\end{array}$} & \multirow{2}{*}{$\begin{array}{c}\text { Joint } \\
43(10.4)\end{array}$} & \multirow{2}{*}{$\begin{array}{c}\text { Individual } \\
0(0.0)\end{array}$} \\
\hline 1. & Food and beverages. & & & & & \\
\hline 2. & Meal outside the home. & $235(56.6)$ & $108(26.0)$ & $11(2.7)$ & $60(14.5)$ & $1(0.2)$ \\
\hline 3. & Clothing and footwear. & $90(21.7)$ & $253(61.0)$ & $7(1.7)^{\prime}$ & $54(13.0)$ & $11(2.7)$ \\
\hline 4. & Communication equipment. & $257(61.9)$ & $82(19.8)$ & $16(3.9)$ & $52(12.5)$ & $8(1.9)$ \\
\hline 5. & Household electrical appliances. & $216(52.0)$ & $152(36.6)$ & $4(1.0)$ & $42(10.1)$ & $1(0.2)$ \\
\hline 6. & Furniture/home furnishings. & 108(26.0) & $248(59.8)$ & $3(0.7)$ & $54(13.0)$ & $2(0.5)$ \\
\hline 7. & Vehicles. & $325(78.3)$ & $39(9.4)$ & $6(1.4)$ & $42(10.1)$ & $3(0.7)$ \\
\hline 8. & Real estates. & $275(66.3)$ & $56(13.5)$ & $1(0.2)$ & $81(19.5)$ & $2(0.5)$ \\
\hline 9. & Medicine. & 196(47.2) & 144(34.7) & $2(0.5)$ & $70(16.9)$ & $3(0.7)$ \\
\hline 10. & Children education. & 163(39.3) & 143(34.5) & $3(0.7)$ & $106(25.5)$ & $0(0.0)$ \\
\hline 11. & Life insurance. & $225(54.2)$ & $93(22.4)$ & $1(0.5)$ & $95(22.9)$ & $1(0.2)$ \\
\hline 12. & Education insurance. & 182(43.9) & $119(28.7)$ & $6(1.4)$ & $107(25.8)$ & $1(0.2)$ \\
\hline 13. & Family vacations. & 183(44.1) & $143(34.5)$ & $5(1.2)$ & $83(20.0)$ & $1(0.2)$ \\
\hline 14. & Money for the parents. & 163(39.3) & $132(31.8)$ & $1(0.2)$ & $107(25.8)$ & $12(2.9)$ \\
\hline
\end{tabular}

On the other hand, the financial decision making by the wife which recorded the highest percentage share involved only three things, namely food and beverages (62.4\%), clothing and footwear (61.0\%) and furniture/home furnishings (59.8\%). Percentage of more than 50 percent in the decision-making also explained that the wife, despite working, only has the 'authority' to make financial decisions that are 'in the family' only. The socio-cultural factors perceived as affecting many of these findings, given that 94.5 percent of the respondents are the Malay Muslims.

Meanwhile, there is no higher share for the husbands' and wives' joint financial decision making. Although the study subjects are married public sector workers (in dual-income families), the jointly financial decision making patterns is not prominent in this study. The cause of the findings cannot be ascertained. Interestingly, there are also individual's financial decisions making, that were made on the same matter. In general, it seems to reflect the individualistic nature among the couples involved. However, it is also not prominent in this finding.

After conducting the factor analysis, four items were eliminated from the 14 items that measure the respondents' financial decision making (FDM), that is, real estates (FDM8), medicine (FDM9), family vacations (FDM13) and money for the parents (FDM14). The analysis factors result indicates that the items measuring the financial decision making can be broken into two constructs, namely the decision making on family basic expenses and the expenditure on protection (insurance) decision-making. If it is refined according to the construct, the husbands still dominate the decision-making on both aspects compared to the wives with each recording; family basic expenses (husband $=46.20 \%$; wife=39.28\%) and insurance expenses (husband=45.78\%; (wife=28.51\%) respectively.

\subsection{Dual-income family financial decision-making patterns}

Figure 1 shows the pattern of the respondents' financial decisions making. This pattern is obtained by summing all the decision making frequencies for the husband, wife, child, together and individually. The results show that the financial decision making in the respondent's family is dominated by the husbands (46.07\%) than wives (34.05\%). The husbands and wives financial decision making were low (15.78\%). While the financial decision making by the children and individuals recorded only about one percent. If referred to the perceptions of the respondents to the question 'decision makings related to spending money in the family should be whose responsibility", the findings recorded husbands (57.6\%), wife (9.6\%) and jointly (32.8\%). This finding indicates that the respondent's practice and perception are not in congruent. This finding explains that the husband still dominates the financial decision making even though his wife had contributed income to the family. 


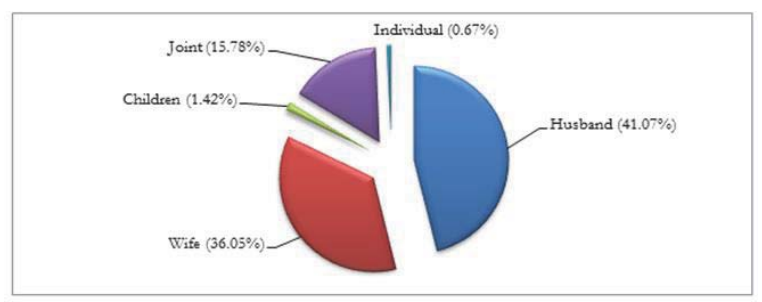

Figure (1). The patterns of the respondents' financial decision making.

Figure 2 specifically shows the respondents' financial decision making by the husbands and wives and jointly (husbandwife). The three most important financial decision making made by the husbands are related to the purchase of vehicles (FDM7), communication equipment (FDM4) and meals outside the home (FDM2). While the most important financial decision made by the wife involved the financial decisions related to food (FDM1), clothing/footwear (FDM3) and furniture/home furnishings(FDM6).

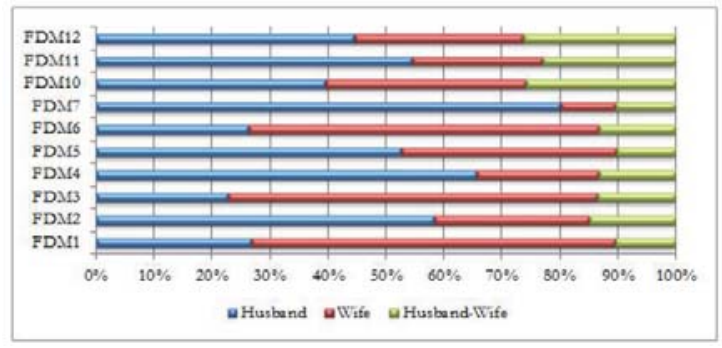

Figure (2). The respondents' financial decision-making

While the highest percentage of financial decision makings that are jointly made involved the financial decision related to the children's education, education insurance, and life insurance. This supports the findings of Safilios-Rothschild (1969) in Egdel (1980), Grassbard-Shectman (2001), Bernasek and Bajtelsmit (2002) and Lindamood and Hanna (2006), that is an important decision that involves large expenditures are dominated by the husbands. While the less important involving little expenditures were made by the wives.

\subsection{Husbands' and wives' Financial Decision Making Score}

The total financial decision making score made by the husbands and wives out of the 10 measured items are shown in Figure 3. The highest score of the husband's financial decision making is six (17.8\%). While the highest wives' financial decision making score is four (18.8\%). Once again, this explains that the husband has an advantage in the family financial decision making process.

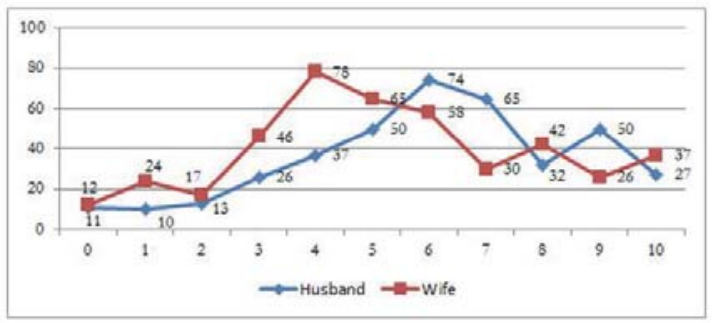

Figure (3). The total financial decision making score 
The following discussion is focused on the minimum score of the financial decision making (score 0 ) and maximum (score 10). By looking at the husband's ' 0 ' score, it was found that eight husbands (72.7\%) are not university graduates, seven husbands (63.6\%) hold positions in the support group and seven (63.6\%) of them contributed higher income share to the family than the wives. While for the wife's score of ' 0 ', nine wives (75.0\%) are not university graduates and hold positions in the support group. Only two wives (16.7\%) contributed larger income than the husband in the family.

Referring to the husbands' score of ' 10 ', it was found that 23 husbands (62.2\%) had non-university education, 24 husbands (64.9\%) in the category of support group and 23 husbands (62.2\%) contributed greater income than the wife in the family. While for the wives' score of '10' it was found that $16(59.3 \%)$ had non-university education and 17 wives (64.0\%) hold positions in the support group. In this situation, only five wives (18.5\%) contributed greater income than the husband in the family.

Based on the descriptive analysis of the score of ' 0 ' and a score of '10' discussed above, it was found that resource factors (financial) alone do not give absolute power in the financial decision making in the family. Instead, there are other factors that influence the financial decision making in the family, such as religious factor, culture and ethnicity (Rodman 1972). The religious factors are among the contributors to the decision making, because in Islam, the husband is the head of the family.

\subsection{Comparison of financial decision making by husband and wife}

Table 3 shows a comparison of the mean scores for the husband's financial decision making to the contribution of the family income. The results of the ANOVA test showed significant differences $[F(d f=2,502, p<.05)=3.620]$ between the average scores of the husband's financial decision making according to the family income contribution. However, the Tukey test results show only the difference score for the husband's financial decision making were significant $(p=.028)$ on the husband's contribution of the family income 'more than' the wife (6.41) and only the contribution of the family income 'husband less than the wife' (5.65).

Table (3). The ANOVA test results on the mean score of the husband's financial decision making according to the husband's family income contribution.

\begin{tabular}{|cccccc|}
\hline Contribution to family income & $\mathrm{n}$ & Mean & Standard Deviation & Fvalue & Significant \\
\hline Husband $>$ Wife & 266 & 6.41 & 2.43 & & \\
Husband $=$ Wife & 46 & 6.07 & 2.26 & 3.620 & $.028^{* *}$ \\
Husband $<$ Wife & 103 & 5.65 & 2.62 & & \\
\hline ** Significant at $p<.05$ & & & &
\end{tabular}

Table 4 shows a comparison of the mean score of the wife's financial decision making with the family income contribution. ANOVA test results show that there are significant differences $[F(\mathrm{df}=2578, p<.05)=5.102]$ between the average score for the wife's financial decision making according to the wife's family income contribution. This finding means that the wife who has income in excess of the husband's income had more opportunities in the family financial decision making. The Tukey test shows that the differences in the average score of the wife's financial decision making is just significant ( $p=.001$ ) only on the contribution of the family income 'husband more than wife' (4.89) and the contribution of the family income 'husband less than wife' (5.75).

Table (4). The ANOVA test results on the mean score of the wife's financial decision making according to the family income contribution.

\begin{tabular}{|cccccc|}
\hline Contribution to family income & $\mathrm{n}$ & Mean & Standard Deviation & Fvalue & Significant \\
\hline Husband $>$ Wife & 266 & 4.89 & 2.57 & 5.102 & $.006^{\star *}$ \\
Husband $=$ Wife & 46 & 5.61 & 2.51 & & \\
Husband $<$ Wife & 103 & 5.75 & 2.31 & & \\
** Significant at $p<.05$ & & & & &
\end{tabular}

Based on the above results of the ANOVA test, on the mean score of the financial decision making on a husband and wife, it was found that resource factor (finance) has a relationship with the family financial decision making. The husband or wife who has a greater income than the spouse in the family has an advantage in the financial decision making. This is 
in line with the assumptions of the Resources Theory (1964) and also the findings of past studies, such as Bernasek and Baitelsmit (2002) and Lindamood and Hanna (2006). However, the religion, culture and ethnicity also have influence in the financial decision making in a family, even if both husband and wife work and contribute to the family.

\section{Conclusions}

The financial decision making patterns among the respondents are still similar to the previous findings, i.e. financial decision making is dominated by either husband, wife or husband-wife. There are also decision making made by the children and individuals, but the percentage is very low and is insignificant to be featured in this study. Financial decision making dominated by the husband are decisions involving large expenses and high commitments, such as an investment. While the financial decision making dominated by the wife is closely related to the expenses pertaining to the needs and the importance of the family. While the collective decision making of the spouses are more directed to the needs of the children. In total, there are three main patterns of the financial decision making (FDM) in the family that is; husband's FDM, wife's FDM and FDM by the spouses. However, the husband still has the advantage of the financial authority in decision making in the dual-income family.

\section{Acknowledgment}

The authors would like to thank and appreciate Universiti Kebangsaan Malaysia for providing of research funding under Grant UKM-SK-21-2007: Financial well-being among public sector in Malaysia 2008.

\section{References}

Ahmad, A. (1999). Gender Role Orientation of Husbands and Work-Family Conflict of Wifes in Dual-Earner Families. Pertanika Journal of Social Science and Humanities. 7(1): 1-9.

Ahmad, A. (2008). Direct and Indirect Effect of Work-Family Conflict on Job Performance. The Journal of International Management Studies. 3(2): 176-180.

Bernasek, A. \& Bajtelsmit, V. L. (2002). Predictors of women's involvement in household financial decision-making. Association for Financial Counseling and Planning Education, 13(2):39-47.

Blau, F. D., Ferber, M. A. \& Winkler, A. E. (2006). The Economics of Women, Men, and Work. $5^{\text {th }}$ edition. New Jersey: Pearson Prentice Hall.

Blood, R. O. \& Wolfe, D. M. (1960). Husband and wife: the dynamics of married living. Glenceo: The Free Press.

Bonke, J. (2008). Income distribution and financial satisfaction between spouses in Europe. The Journal of Socio-Economics. 37: 2291-2303.

Coleman, M. \& Ganong, L. H. (1989). Financial management in step families. Lifestyles: Family and Economic Issues, 10(3):217-232.

Davis, D. S. (1993). Financial security of urban retirees. Journal of Cross-Cultural Gerontology, 8:179-195.

Deacon, R. E. \& Firebough, F. M. (1988). Terj. Nurizan Yahaya dan Mumtazah Othman. Pengurusan sumber keluarga: prinsip dan aplikasi. Serdang: Penerbit UPM.

Economic Planning Unit. (2006). $9^{\text {th }}$ Malaysian Planning 2006-2010. Prime Minister Department of Malaysia.

Foster, A.C. \& Mammen, S. (1992). Impact of wife's employment on service expenditures. Journal of Consumer Studies and Home Economics. 16:9-18.

Goldsmith, E.B. (2005). Resource Management for Individuals and Families. 3rd edition. United States: Thompson Wadsworth.

Grossbard-Schectman, S. (2001). The new home economics at Columbia and Chicago. Feminist Economics, 7(3):103-130.

Gupta, A. E., Walker, T. \& Huston, A. (2008). Working Families Should Not Be Poor. In Crane, D. R. \& Heaton, T. B. Handbook of families and poverty (pp.32-47). London: SAGE Publications.

Hertz, R. (1992). Financial Affairs: Money and Authority in Dual-Earner Marriage. Dalam Lewis, S., Izraeli, D. N. \& Hootsmans, H. Dual-earner families: international perspectives (pp.127-150). London: SAGE Publications.

Jamilah Ariffin. (2001). The changing Malaysian family: tracing its changes through trend data and research findings. In Jamilah Ariffin dan Adeline Louis (pnyt). Family well-being: learning from the past for the betterment in the future. ISI Publication.

Kaur, S. (2008). Women at work: work family conflict and wellbeing. Pertanika Journal Social Science dan Humanity. 16(2): 257-268.

Lindamood, S. \& Hanna, S. D. (2006). The more financially knowledgeable person in older couple households. Consumer Interests Annual, 52:315-330.

Mano-Negrin, R. \& Katz, R. (2003). Money management of dual-earner families in Israel. Journal of Family and Economic Issues, 24(1):49-72.

Muske, G. (1995). Family financial management: a case study from the perspective of the money manager. Family Economics and Resource Management Biennial, 129-134.

Muske, G. \& Winter, M. (2001). An in-depth look at family cash-flow management practices. Journal of Family and Economic Issues, 22(4):353-372. 
Noraini, M. N. (2001). Work, Family and Women's Well-Being: Challenges of Contemporary Malaysian Women. IIUM Press Malaysia. Norzareen, M. \& Nobaya, A. (2010). Women of the sandwich generation in Malaysia. European Journal of Social Sciences. 13(2): 171-178.

Peyton, R. M., Pitts, S. T. \& Kamery, R. H. (2004). The family decision-making process: a review of significant consumer satisfaction/ dissatisfaction models. Academy of Marketing Studies Journal. http://findarticles.com/p/articles/mi_hb6167/is_1_8/ai_n29153 589/ ?tag=content;co11. Assesed on 23rd November 2010.

Rodman, H. (1972). Marital power and the theory of resources in a cross-cultural context. Journal of Comparative Family Studies, 1:5061.

Sabitha Marican. (2005). Membentuk Suasana Kerja Positif: Aspek Hubungan Manusia dan Persekitaran Sosial. Kuala Lumpur: Utusan Publications \& Distributors.

Sabitha Marican. (2011). Wanita Lebih Banyak Alami Stress Mental? Mingguan Malaysia, 23 Januari, 2011.

Samsinar Md. Sidin, et al. (2004). The effect of sex role orientation on family purchase decision making in Malaysia. Journal of Consumer Marketing, 21:381-390.

Stendardi, E. J. \& Graham, J. F. (2006). The impact of gender on the personal financial planning process. Humanomics. 22(4): 223238.

Straus, M. A. Yodanis, C. L. (1995). Marital Power. In Levinson, D. Encyclopedia of Marriage and the Family, pp.437-442. New York: Simon \& Schuster MacMillan.

Winkler, A. E. (1998). Earnings of husbands and wives in dual-earner families. Monthly Labor Review, 42-48.

Yilmazer, T. \& Lyons, A. C. (2010). Marriage and the allocation of assets in women's defined contribution plans. Journal of Family Economic Issues. 31: 121-137.

Zaimah Ramli. (2011). Wanita dan pembuatan keputusan kewangan. Manusia dan Masyarakat, 21:64-75.

Zaimah, R., Sarmila, M.S., Abd Hair Awang, N.Lyndon, Selvadurai, S., Suhana Saad, Azima, A.M. \& Rosniza Aznie, C.R. (2012). Pembuatan keputusan kewangan: kajian kes keluarga dwi-kerjaya di Malaysia. Malaysian Journal of Society and Space, 8(9):53-59.

Zaimah, R., Sarmila, M.S., Selvadurai, S., Lyndon, N., Er, A.C. \& Muhd Norizam Jamian. 2013. The history and current status of dualcareer families in Malaysia. Asian Social Science, 9(6):16-21. 